\title{
LEY FEDERAL DE RESPONSABILIDAD PATRIMONIAL DEL ESTADO
}

Como un producto de la apertura de México sobre todo al mercado mundial a través de los acuerdos de libre comercio y de su incorporación total al Sistema Interamericano de Derechos Humanos con la aceptación de la competencia de la Corte Interamericana de Derechos Humanos (CIDH), uno de los cuestionamientos que surgían, sobre todo en la academia, era: ¿cómo el Estado mexicano iba a indemnizar en caso de responsabilidad patrimonial del Estado. El cuestionamiento surgía por lo que ya se avizoraba, la necesidad de que México hiciera frente a indemnizaciones surgidas de resoluciones o sentencias dictadas en los foros internacionales en donde este país es parte.

La Ley Federal de Responsabilidad Patrimonial del Estado (LFRPE) ${ }^{1}$ "tiene por objeto fijar las bases y procedimientos para reconocer el derecho a la indemnización a quienes, sin obligación jurídica de soportarlo, sufran daños en cualquiera de sus bienes y derechos como consecuencia de la actividad administrativa irregular del Estado".

En la parte internacional, concretamente la LFRPE textualmente establece:

Los preceptos contenidos en el Capítulo II y demás disposiciones de esta Ley serán aplicables, en lo conducente, para cumplimentar los fallos de la Corte Interamericana de Derechos Humanos, así como las recomendaciones de la Comisión Interamericana de Derechos Humanos, aceptadas estas últimas por el Estado Mexicano, en cuanto se refieran a pago de indemnizaciones.

La aceptación y cumplimiento de las recomendaciones a que se refiere el párrafo anterior, en su caso, deberá llevarse a cabo por el ente público

1 Ley publicada en el Diario Oficial de la Federación el 31 de diciembre de 2004. En vigor a partir del 1o. de enero de 2005. 
federal que haya sido declarado responsable; lo mismo deberá observarse para el cumplimiento de los fallos jurisdiccionales de reparación. Será la Secretaría de Relaciones Exteriores el conducto para informar de los cumplimientos respectivos, tanto a la Comisión como a la Corte Interamericana de Derechos Humanos, según corresponda. ${ }^{2}$

El capítulo II se refiere a la indemnización, sus modalidades, la forma de pago, el modo de cálculo etcétera. Como se ve, si bien la ley no trata únicamente sobre la responsabilidad internacional, si hace hincapié en la responsabilidad derivada de la violación de derechos humanos, lo cual tiene un doble resultado. Por un lado es positivo pues se crea un régimen único y de alguna manera privilegiado, pero omite toda responsabilidad derivada de sentencias de otro tipo, con lo que este tipo de asuntos se remite al sistema general de la ley que es de muchos vericuetos. A menos que la expresión señalada en el texto anterior ("lo mismo deberá observarse para el cumplimiento de los fallos jurisdiccionales de reparación") se interprete como aplicable también a sentencias o resoluciones dictadas por organismos de solución de controversias internacionales. De cualquier manera el texto es oscuro, y la impresión es que sólo se le da importancia y preferencia a los fallos de la CIDH y a las resoluciones de la Comisión Interamericana de Derechos Humanos.

Manuel BECERRA RAMÍREZ*

2 Artículo 2 de la LFRPE.

* Investigador del Instituto de Investigaciones Jurídicas de la UNAM. 